\title{
Library Cooperation at Duke and North Carolina Universities
}

In this article Mr. Pratt, head of circulation at Duke University Library, stresses the flexibility of the cooperative library program of Duke University and the University of North Carolina.

\section{THE DUKE-UNIVERSITY OF NORTH \\ 1 carolina cooperation program ${ }^{1}$ be-} gan in the Autumn of 1933 when a joint committee was appointed by the presidents of these two institutions to formulate plans for cooperation in certain common educational undertakings. One phase of this program concerned the correlation of the resources of the two university libraries under a cooperative purchasing plan.

The two libraries were studied with a view of eliminating, as far as possible, duplication of library purchases. It was found that these libraries, for the most part, had special collections which supplemented rather than duplicated each other. In the University of North Carolina, for example, there were special collections on the history of books, American and Spanish drama, North Carolinana, rural social economics, bibliography, mycology, etc. At Duke University special collections included newspapers, Latin American his-

1 For previous accounts of this cooperation pro. gram, the reader is referred to the following articles: Branscomb, H. and Downs, R. B., "Plan for University Library Cooperation," School and Society,

42: 64-6, July 13, 1935. University Library Cooperation," Library Journal, $60: 877 \cdot 79$, Nov. 15, 1935 . tory, French literature, early Americana, transportation, entomology, and eighteenth century poetry and prose. Taking their special collections as a beginning, Duke University and the University of North Carolina found in them a sound basis for cooperation.

\section{Basis for Program}

This program is based on the following general principles.

There is a concentration in each library of materials dealing with specialized problems or fields of knowledge in which one institution is primarily interested; for example, Duke has a school of forestry and a graduate school of religion, while the University of North Carolina has a strong department of geology and a school of library science.

In some fields the research interests and activities of the departments in the two universities are practically identical. The practice here is to avoid, as far as possible, the duplication of expensive materials, such as files of periodicals and publications of learned societies. Much of this type of materials can be divided arbitrarily between the two libraries.

There remains a correlation of certain of the activities of the libraries which fall under no departmental heading, such as documents, newspapers, reference tools, academy and society publications, etc. Here again some arbitrary agreement 
needs to be made. With regard to newspapers, the University of North Carolina Library is concerned with the preservation of North Carolina papers. Duke University, on the other hand, is receiving and preserving important national newspapers from various regions of the United States and also a number of outstanding foreign newspapers. The two libraries have agreed to the following cooperative plan in the acquisition of state documents: (I) both libraries are to acquire all the current documents of North Carolina, South Carolina, Tennessee, and Virginia; (2) Duke University is responsible for the acquisition of documents from Alabama, Arizona, California, Colorado, Connecticut, Florida, Georgia, Illinois, Indiana, Kansas, Maine, Massachusetts, Michigan, Minnesota, Nevada, New Hampshire, New Mexico, Oklahoma, Rhode Island, Texas, Utah, Vermont, and Wisconsin. The University of North Carolina Library is responsible for the remaining twenty-one states; (3) whenever a faculty member of either institution should require a particular item for class or research purposes, the document division of the library which regularly serves his needs may acquire the material though such procedure conflicts with the above allocation; (4) the plan of cooperation should be adhered to in the acquisition of departmental reports, such as auditor, treasurer, etc.; (5) both libraries will collect the manuals or legislative directories of all states; and (6) since the University of North Carolina Library is a depository particularly for all state journals and laws, it is deemed advisable that the document division of that institution should continue to acquire those items from all states, while Duke will secure the journals and laws of the states for which it is responsible.

\section{Author Cards Duplicated}

The General Education Board of New York made a grant of $\$ 12,500$ in the Spring of 1934 to be used in duplicating and exchanging the author cards of the two libraries. These cards were dexiographed in August, I935, by Remington Rand Corporation at a cost of three cents per card. New cards for current accessions have since been regularly exchanged. The exchange of card catalogs has facilitiated the avoidance of duplication and has made the resources of each library available to the students and faculty of the neighboring institution.

Since the amount of borrowing between the two libraries tended to increase as the fields of specialization became more distinct, a daily messenger service was inaugurated in April, 1935. The amount of borrowing between the two libraries has increased fourteen times since the exchange of author cards and the inauguration of the daily messenger service (see Table I). These figures do not take into

TABLE I

\begin{tabular}{|c|c|c|}
\hline Date & $\begin{array}{l}\text { Number of } \\
\text { books lent by } \\
\text { Duke }\end{array}$ & $\begin{array}{l}\text { Number of } \\
\text { books lent by } \\
\text { Univ. N.C. }\end{array}$ \\
\hline $\begin{array}{l}\text { I } 929-30 \\
\text { I } 930-31 \\
\text { I } 931-32 \\
\text { I } 932-33 \\
\text { I } 933-34 \\
\text { I } 934-35 \\
\text { I } 935-36 \\
\text { I936-37 } \\
\text { I937-38 } \\
\text { I938-39 } \\
\text { Sept. I, 1939- } \\
\text { Jan I, I94I }\end{array}$ & $\begin{array}{r}21 \\
60 \\
40 \\
60 \\
74 \\
190 \\
471 \\
738 \\
1221 \\
815 \\
\\
955\end{array}$ & $\begin{array}{r}5 \text { I } \\
95 \\
65 \\
\text { I I I } \\
82 \\
346 \\
3486 \\
\text { I } 875 \\
\text { I } 4758 \\
\text { I } 28 \\
\text { I } 74 \\
\text { I } 301\end{array}$ \\
\hline
\end{tabular}

account the large amount of borrowing that is done direct by students and faculty members. This direct borrowing is great because the two universities are only nine miles apart and full privileges are extended to faculty and graduate students at either library. 


\section{Grant for Research Collections}

In December, 1935, the General Education Board made a generous grant of $\$ 50,000$ to be divided equally between the two libraries. This fund was used to build up research collections in the biological, physical and social sciences, and English literature. An effort was made to avoid duplicating the holdings of either library. Therefore, everything acquired through the grant was an addition to the total resources of the two libraries. Particular attention has been directed toward securing materials of special significance to this region.

The total periodical resources of this area have been greatly increased since 1935, when both libraries agreed to exchange current periodical numbers as well as books. Since this date the two libraries have avoided as far as practical further duplication of the current periodicals allotted to the other institution.

By June, I936, the daily messenger service had proved indispensable, and it was decided by mutual agreement to continue it through the summer terms.

From April, 1935, to September, I939, this daily exchange of books had been handled by students traveling from one campus to another; but the increasing amount of borrowing made it necessary to place the service on a more substantial basis. This being the case, arrangements were made for the joint purchase and operation of a station wagon. It is proposed that the station wagon carry students and faculty members as well as books and other items. The schedule will be adjusted to the use made of this vehicle.

\section{Borrowing Privileges Extended}

Another progressive step was made in September, 1939, when both libraries ex- tended borrowing privileges to the North Carolina College for Negroes, located in Durham. For the first time this institution was offering graduate courses in commercial education, English, education, science, and social science leading to a Master's degree. The resources of its library were limited; so Duke and the University of North Carolina came to its aid. The station wagon now includes this institution in its rounds when there is material to be borrowed or returned.

In June, I94 I, the Rockefeller Foundation made a grant of $\$ 75,000$ to be divided equally between Duke University, the University of North Carolina, and Tulane University for the acquisition of Latin American materials. The division of the field was geographical with subject divisions cutting across the geographical assignment in special cases. This grant is to be spent over a five-year period.

\section{Program in Eighth Year}

This program is now in its eighth year of operation and has passed far beyond the experimental stage. It must, however, of necessity be flexible, calling for constant expansion and adjustment. This is made necessary by progress in research, addition of faculty members and new departments. Complete elimination of duplication is not possible nor intended. The real purpose of such cooperation is the elimination of duplication of rare and expensive materials of a research nature, thereby increasing the total resources of the two libraries. The result of this cooperation has been the creation in the Durham-Chapel Hill area of one of the important library centers of the South.

The faculties of the two universities were frequently consulted in making the study of major research interests. In 
some instances there were joint meetings of faculty representatives of departments to determine an intelligent and practical division of fields in which library collections were to be developed.

This program could very easily be expanded to include four or five other col-

\section{Encouraging Freshmen to Read}

(Continued from page 125)

of seven days. According to the records kept by the librarians over a number of years, an average of about seventy-five students withdraw books daily.

The expense for equipping and operating the Freshman Reading Room exclusive of the cost of processing and servicing the books, has amounted to \$I 8 Io: furniture (desk, shelves etc.) \$3IO; books purchased in 1937) \$800; and books (purchased since I937) \$700. In the spring of I940, the committee selected IOI books for addition to the collection and added 20 additional copies of books already on the list.

\section{Students Benefit More}

The exact measurement of the values of a freshman reading room is impossible, no doubt, but, since the opening of the room, most of us who are members of the rhetoric staff have felt that students have benefited much more from their supplementary reading than they did in the old days before they had direct access to the books and had to make their selections without the privilege of examination. Among other valuable results generally agreed upon by the older instructors are: leges and universities located within a fifty mile radius. A beginning along this line has already been made at the University of North Carolina where a joint cata$\log$ of all books of a research nature found in North Carolina libraries is being collected.

I. The freshmen approach their supplementary reading much more favorably than they used to.

2. More freshmen are reading books from the collection in addition to the minimum requirement of three per semester.

3. Better book reviews appear more often.

4. The Freshman Reading Room has served as an introduction to the facilities of the library to many of our students.

The problem of supplementary reading has always been difficult, as every instructor knows and the results are frequently unsatisfactory. Yet there are few instructors who do not believe it is worth while.

At the University of Illinois, the problem of supplementary reading has been at least partially solved through the successful operation of the Freshman Reading Room. Much of the credit for what has been accomplished must go to the members of the library staff who have not only granted the requests made by our staff but have also cooperated enthusiastically in our attempt to encourage freshmen to read. 